\title{
Potential of an Indigenous Fungus, Plectosporium tabacinum, as a Mycoherbicide for Control of Arrowhead (Sagittaria trifolia)
}

Young Ryun Chung, Associate Professor, Department of Microbiology, Gyeongsang National University, Chinju 660-701, Korea; Suk Jin Koo, Senior Scientist, Agrochemical Research Center, LG Chemical Ltd., Science Town, Taejeon 305-380, Korea; and Heung Tae Kim, Senior Scientist, and Kwang Yun Cho, Director, Screening and Toxicology Center, Korea Research Institute of Chemical Technology, Taejeon 305-384, Korea

\begin{abstract}
Chung, Y. R., Koo, S. J., Kim, H. T., and Cho, K. Y. 1998. Potential of an indigenous fungus, Plectosporium tabacinum, as a mycoherbicide for control of arrowhead (Sagittaria trifolia). Plant Dis. 82:657-660.

An isolate of the indigenous fungus Plectosporium tabacinum was isolated from arrowhead (Sagittaria trifolia) in Yusung, Korea in 1990 and evaluated in laboratory and growth chamber tests as a potential mycoherbicide. The fungus grew comparatively slowly on potato dextrose agar and corn meal agar, attaining a diameter of $65 \mathrm{~mm}$ after 12 days at $25^{\circ} \mathrm{C}$. Conidia were mass-produced in shake-cultures or in a fermentor using potato dextrose broth containing yeast extract $(0.5 \%, \mathrm{wt} / \mathrm{vol})$ at $25^{\circ} \mathrm{C}$. When arrowhead seedlings at the 2- to 3-leaf stage were inoculated with conidial suspensions $\left(2 \times 10^{7}\right.$ conidia/ml $)$ and incubated in a dew chamber for $18 \mathrm{~h}$ at $25^{\circ} \mathrm{C}$, the plants developed small, brown spots on the leaves and petioles in 2 days, and were blighted completely within 7 days after inoculation. This effect was consistent on arrowhead plants from the 2- to 5-leaf stage. Another arrowhead species, S. pygmaea, was as susceptible as $S$. trifolia to the pathogen. Several crops, including rice, barley, and wheat and 34 other common weed species, were immune. In small-scale field tests in paddy fields during the summers of 1992 and 1993, a mean reduction of $71.3 \%$ in the number of arrowhead plants was observed following a foliar spray of a conidial suspension $\left(10^{7}\right.$ conidia $\left./ \mathrm{ml}\right)$. These results indicate that $P$. tabacinum has potential as a selective mycoherbicide for arrowhead control.
\end{abstract}

Additional keywords: bioherbicide, biological control, paddy weed perennial weed in the family of Alismataceae and propagates by underground tubers. The weed is present throughout eastAsian rice areas and is considered to be difficult to control with herbicides due to herbicide tolerance and season-long emergence (10). In Korea and Japan, this weed has been ranked as the number one or two weed problem in most rice paddy fields $(9,10)$. Yield losses caused by this weed were a $20 \%$ reduction in the number of rice ears and a $23 \%$ reduction in the weight of husked rice when 20 tubers of the weed were buried per square meter of paddy at

In the summer of 1990, a pathogenic fungus was isolated from blighted petioles and leaves of arrowhead and tentatively identified as an Acremonium sp. (7). The

Corresponding author: Young Ryun Chung

E-mail: yrchung@nongae.gsnu.ac.kr

This research was supported in part by NonDirected Research Fund, Korea Research Foundation, 1993.

Accepted for publication 28 February 1998.

Publication no. D-1998-0403-01R

(C) 1998 The American Phytopathological Society
Arrowhead (Sagittaria trifolia L.) is a transplanting of rice seedlings (9). disease was severe on both young and old arrowhead plants from June to October in paddy fields in the Yusung area in Korea. Disease symptoms occurred on the leaf, seed, and petiole of arrowhead. Small, brown spots developed initially on areas infected, then spots extended to form large necrotic lesions, resulting in the eventual wilting and blighting of the plant. Infection of the petiole frequently induced defoliation within a few days under hot and humid conditions (7).

From microscopic examination of several isolates and cultural characteristics, the fungus has been reidentified as Plectosporium tabacinum (van Beyma) M. E. Palm, W. Gams et Nirenberg by W. Gams, Centraalbureau voor Schimmelcultures, The Nether- lands (personal communication). This genus is similar to the genus Acremonium (11).

The objective of this study was to explore the potential of this fungus as a mycoherbicide for arrowhead under laboratory and growth chamber conditions. Experiments were conducted to determine the effect of temperature on the growth of the fungus; the effects of dew period, temperature, and inoculum concentration on disease development; and the host range of the pathogen. Efficacy in small-scale field trials also was evaluated.

\section{MATERIALS AND METHODS}

Isolation, culture, and pathogenicity test. The fungus was isolated from diseased arrowhead petioles and seeds collected from the Yusung area in Korea by rinsing sections of diseased tissue in $0.5 \%$ $\mathrm{NaOCl}$ for 1 min and placing sections on potato dextrose agar (PDA) supplemented with $100 \mu \mathrm{g} / \mathrm{ml}$ streptomycin sulfate. The plates were incubated for 10 days at $25^{\circ} \mathrm{C}$ and pieces of mycelium containing abundant conidia from the colonies were transferred to fresh PDA for subsequent experiments. Conidia were collected from 10- to 12-day-old colonies grown on PDA, placed in cryopreservative (10\% glycerol) in $1.5-\mathrm{ml}$ plastic cryovials, and stored at $-70^{\circ} \mathrm{C}$. The isolate YC8-7 has been deposited in the Korean Collection for Type Cultures (KCTC) with the assigned number KCTC 0109BP.

Pathogenicity of 21 isolates of $P$. tabacinum was tested by inoculation of a conidial suspension $\left(10^{6}\right.$ conidia $\left./ \mathrm{ml}\right)$ on arrowhead seedlings (2- to 3-leaf stage). Immediately after inoculation, the plants were placed in the dark in a dew chamber for $12 \mathrm{~h}$ at $25^{\circ} \mathrm{C}$ and then transferred to a growth chamber at $25^{\circ} \mathrm{C}$. The plants were
Table 1. Radial growth of Plectosporium tabacinum isolate YC8-7 on various media after 11 days of incubation at different temperatures

\begin{tabular}{lcccc}
\hline & \multicolumn{4}{c}{ Colony diameter $(\mathbf{m m})^{\mathbf{y}}$} \\
\cline { 2 - 5 } Temperature (C) & $\mathbf{L B A}^{\mathbf{z}}$ & PDA & CZA & CMA \\
\hline 18 & $43 \mathrm{a}$ & $43 \mathrm{a}$ & $41 \mathrm{a}$ & $41 \mathrm{a}$ \\
20 & $52 \mathrm{~b}$ & $51 \mathrm{~b}$ & $53 \mathrm{~b}$ & $51 \mathrm{~b}$ \\
25 & $66 \mathrm{c}$ & $65 \mathrm{c}$ & $65 \mathrm{c}$ & $65 \mathrm{c}$ \\
30 & $69 \mathrm{c}$ & $68 \mathrm{c}$ & $64 \mathrm{c}$ & $69 \mathrm{c}$ \\
\hline
\end{tabular}

${ }^{y}$ Mean values of two experiments with three replications per treatment. Means followed by the same letter in a column are not significantly different according to Duncan's multiple range test $(P=$ $0.05)$

${ }^{\mathrm{z}}$ LBA, lima bean agar; PDA, potato dextrose agar; CZA, Czapek agar; CMA, cornmeal agar. 
monitored for disease development for a week. Among tested isolates, the most virulent two isolates, YC8-7 and YC8-16, were evaluated in further tests. Inoculum of each isolate was produced in liquid shake culture or in fermentors in potatodextrose broth (PDB) supplemented with yeast extract $(0.5 \%$, wt/vol). The fungal culture was filtered through three layers of cheesecloth to collect conidia and the conidial suspension was adjusted to $10^{7}$ con$\mathrm{idia} / \mathrm{ml}$ with distilled water in all experiments, except as indicated for the inoculum level study.

Effect of temperature on radial growth. For measuring radial growth of $P$. tabacinum, a mycelial disc (5-mm-diameter) taken from an actively growing culture of the fungus (isolate YC8-7) was placed mycelia-side down in the center of a petri plate containing lima bean agar (LBA), PDA, Czapek agar (CZA), or cornmeal agar (CMA). All agar media were products of Difco Laboratories, Detroit. Three replicate plates were incubated at 18,20,25, or $30^{\circ} \mathrm{C}$. Colony diameter was measured after 11 days and the experiment was repeated twice.

Plant preparation. Tubers of mature arrowhead plants were collected from naturally occurring field populations in the fall of 1990 from a rice paddy at the Korea Research Institute of Chemical Technology (KRICT), Taejeon, Korea, and stored at $4^{\circ} \mathrm{C}$. The tubers were planted in styrofoam pots (surface area $75 \mathrm{~cm}^{2}$ ) filled with a sandy loam soil collected from the rice field, and grown until the growth stage appropriate for experiments was obtained. Plants for the host range tests were selected and prepared according to the method developed by the Screening and Toxicology Center, KRICT, established for herbicides screening tests $(5,15)$. Most plants were grown from seeds sown in plastic pots $(20 \times 15 \times 6 \mathrm{~cm})$ filled with sterilized sandy loam soil, and grown in a greenhouse maintained at 28 and $20^{\circ} \mathrm{C}$, day and night, respectively. Bindweed was grown from tuberous root sections. At the

Table 2. Effect of inoculum concentration of Plectosporium tabacinum isolates YC8-7 and YC8-16 on mortality of arrowhead seedlings placed in a growth chamber for 4 days after incubating for $20 \mathrm{~h}$ in a dew chamber at $25^{\circ} \mathrm{C}$

\begin{tabular}{lcc}
\hline & \multicolumn{2}{c}{ Percent mortality } \\
\cline { 2 - 3 } Conidia/ml & YC 8-7 & YC 8-16 \\
\hline $6 \times 10^{3}$ & $37.5 \mathrm{a}$ & $0.0 \mathrm{a}$ \\
$6 \times 10^{4}$ & $80.0 \mathrm{~b}$ & $4.3 \mathrm{a}$ \\
$6 \times 10^{5}$ & $92.5 \mathrm{~b}$ & $20.8 \mathrm{a}$ \\
$6 \times 10^{6}$ & $95.0 \mathrm{~b}$ & $29.3 \mathrm{a}$ \\
$6 \times 10^{7}$ & $100.0 \mathrm{~b}$ & $70.8 \mathrm{~b}$ \\
$6 \times 10^{8}$ & $100.0 \mathrm{~b}$ & $82.0 \mathrm{~b}$ \\
\hline
\end{tabular}

${ }^{\mathrm{z}}$ Mean values of two experiments with three replications per treatment. Means followed by the same letter in a column are not significantly different according to Duncan's multiple range test $(P=0.05)$. time of inoculation, the growth stage of grass plants was between the second and third leaf, and that of the broadleaf plants was between the first and second true leaf.

Effect of inoculum concentration, dew period, and growth stage on disease. Arrowhead seedlings were inoculated with conidial suspensions of $6 \times 10^{3}$ to $6 \times 10^{8}$ conidia/ml and placed in the dark in a dew chamber for $20 \mathrm{~h}$ at $25^{\circ} \mathrm{C}$. Control plants were sprayed with distilled water. Following the dew treatment, the plants were placed in a greenhouse and mortality was recorded after 4 days.

To investigate the effect of dew period on disease development, arrowhead seedlings (2- to 3-leaf stage) were sprayed with conidial suspensions of the isolate YC8-7 containing $2 \times 10^{7}$ conidia/ml and placed in the dew chamber in the dark at $100 \%$ relative humidity $(\mathrm{RH})$ for $4,8,18$, or $24 \mathrm{~h}$ at $25^{\circ} \mathrm{C}$ before removal to greenhouse benches maintained at 28 and $20^{\circ} \mathrm{C}$ (daynight). The plants were monitored for dis-



Fig. 1. Effect of dew period length on mortality of arrowhead seedlings (2- to 3-leaf stage) inoculated with Plectosporium tabacinum isolates YC8-7 or YC8-16. Means followed by the same letter for a dew period are not significantly different according to Duncan's multiple range test $(P=0.05)$.

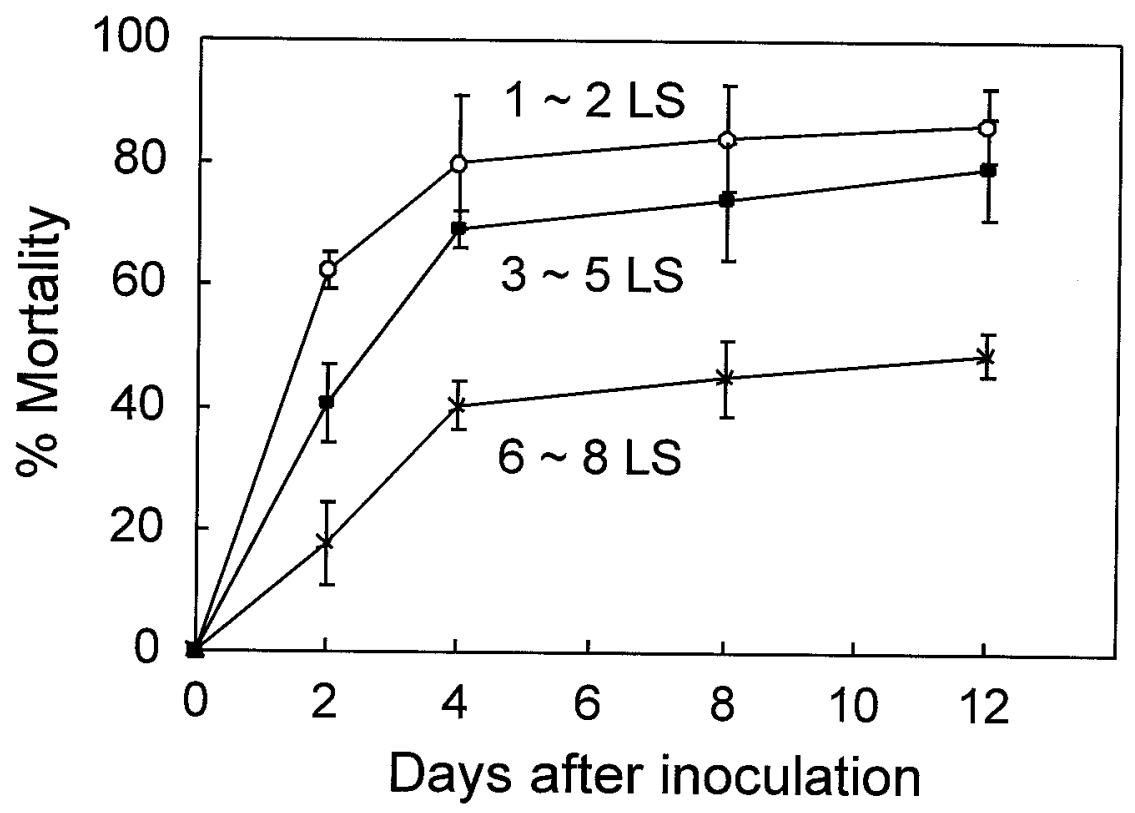

Fig. 2. Effect of Plectosporium tabacinum isolate YC8-7 on mortality of arrowhead at various stages of growth. The plants were inoculated with a conidial suspension $\left(2 \times 10^{7}\right.$ conidia $\left./ \mathrm{ml}\right)$ and disease development was assessed 4 days after inoculation. Bars represent the standard error of the mean. LS $=$ leaf stage. 
ease development for 4 days. Development of the disease on arrowhead at various stages of growth was observed for 12 days after inoculation. The experiments consisted of three replicates and were repeated two times.

Host-range tests. Seedlings of test plants were sprayed with suspensions containing $2 \times 10^{7}$ conidia/ml of isolate YC8-7 and incubated in the dark in a dew chamber for $20 \mathrm{~h}$ at $25^{\circ} \mathrm{C}$. One noninoculated pot of each species was included as a control. Plant responses were considered either immune (no visible reaction) or susceptible on a scale of 1 to 3 , where $1=$ small lesion, $2=$ partial blight, and $3=$ complete blight and death, rated by visual observation after 10 days of incubation in the greenhouse.

Field studies. In 1992 and 1993, the pathogen was tested under field conditions in the Chinju area, Korea. Twenty arrowhead tubers and 15 rice seedlings ( 25 days old) of the cultivar "Dongjin" were planted simultaneously in $2.0-\mathrm{m}^{2}$ paddy fields on 22 May 1992 and 25 May 1993 during the normal transplanting season for rice. All plots were constructed with polyvinyl chloride plate enclosures $(1.4 \times 1.4 \times 0.3 \mathrm{~m}$

Table 3. Reaction of various crop and weed species to Plectosporium tabacinum isolate YC8-7

\begin{tabular}{|c|c|c|}
\hline Family, scientific name & Common name & Disease reaction $^{2}$ \\
\hline \multicolumn{3}{|l|}{ Alismataceae } \\
\hline Sagittaria pygmaea Miq. & Arrowhead & S-3 \\
\hline S. trifolia $\mathrm{L}$. & Arrowhead & $\mathrm{S}-3$ \\
\hline \multicolumn{3}{|l|}{ Amaranthaceae } \\
\hline Amaranthus lividus $\mathrm{L}$. & Pigweed & I \\
\hline \multicolumn{3}{|l|}{ Chenopodiaceae } \\
\hline Chenopodium album $\mathrm{L}$. & Lamb's-quarters & I \\
\hline \multicolumn{3}{|l|}{ Commelinaceae } \\
\hline Commelina communis $\mathrm{L}$. & Asiatic dayflower & I \\
\hline \multicolumn{3}{|l|}{ Compositae } \\
\hline Bidens pilosa $\mathrm{L}$. & Beggar-ticks & I \\
\hline Xanthium strumarium L. & Cocklebur & I \\
\hline \multicolumn{3}{|l|}{ Convolvulaceae } \\
\hline Calystegia japonica Choisy & Bindweed & I \\
\hline Ipomoea nil (L.) Roth & Japanese morning-glory & $\mathrm{S}-1$ \\
\hline \multicolumn{3}{|l|}{ Cruciferae } \\
\hline Brassica napus L. & Rape & I \\
\hline Raphanus sativus $\mathrm{L}$. & Radish & I \\
\hline Lepidium sativum $\mathrm{L}$. & Garden cress & I \\
\hline \multicolumn{3}{|l|}{ Cyperaceae } \\
\hline Cyperus differmis $\mathrm{L}$. & Small-flowered umbrella sedge & I \\
\hline Cyperus serotinus Rottb. & Flat sedge & I \\
\hline Eleocharis kuroguwai Ohwi & Water nutsedge & I \\
\hline Scirpus juncoides Roxb. & Bulrush & I \\
\hline \multicolumn{3}{|l|}{ Gramineae } \\
\hline Agropyron smithii Rydb. & Wheat grass & I \\
\hline Avena fatua $\mathrm{L}$. & Red oat & I \\
\hline Avena sativa $\mathrm{L}$. & Oat & I \\
\hline Digitaria sanguinalis (L.) Scop. & Large crabgrass & I \\
\hline Echinochloa crus-galli P. Beau. & Barnyard grass & I \\
\hline Eleusine indica (L.) Gaertn. & Goose grass & I \\
\hline Eragrostis ferrunginea P. Beauv. & Love grass & I \\
\hline Hordeum sativum Jessen & Barley & I \\
\hline Oryza sativa $\mathrm{L}$. & Rice & I \\
\hline Panicum dichotomiflorum Michx. & Fall panicum & I \\
\hline Setaria viridis $\mathrm{L}$. & Green foxtail & I \\
\hline Sorghum bicolor Moench & Grain sorghum & I \\
\hline Triticum aestivum $\mathrm{L}$. & Wheat & I \\
\hline Zea mays $\mathrm{L}$. & Corn & I \\
\hline \multicolumn{3}{|l|}{ Malvaceae } \\
\hline Abutilon theophrasti Medik. & Velvet-leaf & I \\
\hline Gossypium hirsutum L. & Cotton & I \\
\hline Sida spinosa $\mathrm{L}$. & Prickly sida & I \\
\hline \multicolumn{3}{|l|}{ Leguminosae } \\
\hline Aeschynomene indica $\mathrm{L}$. & Indian joint-vetch & I \\
\hline Glycine $\max \mathrm{L}$. & Soybean & I \\
\hline Trifolium repens $\mathrm{L}$. & White clover & I \\
\hline \multicolumn{3}{|l|}{ Polygonaceae } \\
\hline Polygonum hydropiper L. & Smartweed & I \\
\hline Rumex japonicus Houtt & Dock & I \\
\hline \multicolumn{3}{|l|}{ Pontederiaceae } \\
\hline Monochoria vaginalis Presl. & Monochoria & I \\
\hline \multicolumn{3}{|l|}{ Solanaceae } \\
\hline Datura stramonium L. & Jimson-weed & S-2 \\
\hline Solanum nigrum L. & Black nightshade & I \\
\hline
\end{tabular}

${ }^{\mathrm{z}} \mathrm{S}=$ susceptible on a scale of 1 to 3 , where $1=$ small lesion, $2=$ partial blight, and $3=$ complete blight and plant death; $\mathrm{I}=$ immune.

high). On 23 July 1992 and 20 July 1993, 20 arrowhead plants in each plot were sprayed with 1 liter of a conidial suspension of $P$. tabacinum $\left(10^{7}\right.$ conidia/ml $)$. After 2 weeks, the number of remaining arrowhead plants was counted. Treated and untreated control plots were replicated four times and Duncan's multiple range test was used to separate means $(P=0.05)$.

\section{RESULTS}

The fungus grew fastest at $30^{\circ} \mathrm{C}$ on LBA, PDA, and CMA, with mean colony diameters of 69,68 , and $69 \mathrm{~mm}$, respectively. Growth was reduced significantly at $18^{\circ} \mathrm{C}$ on all media compared to other incubation temperatures (Table 1). Abundant conidia were produced on PDA and CMA at 25 to $30^{\circ} \mathrm{C}$.

The isolate YC8-7 was more virulent than YC8-16, with a concentration of $6 \times$ $10^{4}$ conidia/ml for YC8-7 showing a similar efficacy as $6 \times 10^{8}$ conidia/ml of YC816 when incubated for $20 \mathrm{~h}$ in a dew chamber at $25^{\circ} \mathrm{C}$ (Table 2). The isolate YC8-7 killed all seedlings at a conidial concentration of $6 \times 10^{7}$ conidia $/ \mathrm{ml}$ and above. At a dew temperature of $25^{\circ} \mathrm{C}$, mortality of arrowhead seedlings for isolate $\mathrm{YC} 8-7$ was $65,92,97$, and $98 \%$ after $4,8,18$, and $24 \mathrm{~h}$ of dew, respectively (Fig. 1). Mortality for YC8-16 was lower than YC8-7 for a dew period of less than $18 \mathrm{~h}$.

Arrowhead in the 1- to 2- or 3- to 5-leaf stages was highly susceptible to $P$. $t a b$ acinum, and susceptibility decreased with plant maturity (Fig. 2). The mortality of arrowhead in the 6- to 8-leaf stage was $50 \% 12$ days after inoculation.

Only arrowhead plants in the family of Alismataceae were highly susceptible to $P$. tabacinum (Table 3). Small, restricted lesions developed on seedlings of Japanese morning-glory and Jimson-weed. No reaction occurred on other plant species tested.

In field experiments in both 1992 and 1993, the number of arrowhead stands in plots treated with $P$. tabacinum was significantly lower than that of non-treated plots (Table 4). The isolate YC8-7 reduced

Table 4. Arrowhead stand in field plots ${ }^{\mathrm{x}}$ treated with conidial suspensions of Plectosporium tabacinum isolates

\begin{tabular}{lrr}
\hline Isolate $^{\mathbf{y}}$ & $\mathbf{1 9 9 2}^{\mathbf{z}}$ & $\mathbf{1 9 9 3}$ \\
\hline YC 8-7 & $4.0 \mathrm{a}$ & $4.3 \mathrm{a}$ \\
YC 8-16 & $5.7 \mathrm{a}$ & $5.5 \mathrm{a}$ \\
Untreated check & $13.7 \mathrm{~b}$ & $15.2 \mathrm{~b}$ \\
\hline
\end{tabular}

x Plots $\left(2 \mathrm{~m}^{2}\right)$ were established within natural paddy fields by planting 20 arrowhead tubers simultaneously with 15 rice seedlings.

${ }^{y}$ In each plot, 20 arrowhead plants were sprayed with 1 liter of a conidial suspension of $P$. tabacinum $\left(10^{7}\right.$ conidia $\left./ \mathrm{ml}\right)$.

${ }^{z}$ Values are the mean numbers of arrowhead stands from four replications 2 weeks after treatment. Means followed by the same letter in a column are not significantly different according to Duncan's multiple range test $(P$ $=0.05$ ). 
stands by 70.8 and $71.7 \%$ in 1992 and 1993, respectively. The two isolates YC8-7 and YC8-16 did not differ in their ability to reduce arrowhead stands. Diseased arrowhead in treated plots 2 weeks after inoculation was blighted completely, whereas the plants in the untreated plots were healthy and vigorous.

\section{DISCUSSION}

The results of the experiments conducted show that $P$. tabacinum has potential as a mycoherbicide for controlling arrowhead. $P$. tabacinum has been recently described as a new name for Fusarium tabacinum, the anamorph of Plectosphaerella cucumerina (11). This fungus has been known to incite a number of diseases in crop plants including sunflower, cucurbits, tomato, and other hosts $(1,12,16)$. The isolates of $P$. tabacinum used in this study caused necrosis, blight, and wilting of arrowhead within a short period after inoculation of a conidial suspension. The highly virulent isolate YC8-7 consistently induced disease over a wide range of inoculum concentrations with a 10-h dew period. The requirement of long periods of free moisture for infection is generally one of the principal constraints to the development of many fungal pathogens as mycoherbicides $(3,4)$. In the case of this pathogen, however, the disease developed in a relatively short dew period and the application of the fungus in highly humid rice paddy fields could negate this problem.

Arrowhead seedlings of less than 5-leaf stage were susceptible to $P$. tabacinum, and the susceptibility decreased significantly with plant maturity. This suggests that the fungal inoculum should be applied to the weed in the seedling stage for effective control. The fungus proved to be highly host-specific to the Sagittaria genus and nonpathogenic to crop or other weed species tested, except two weed species, and therefore could be used as a mycoherbicide $(13,15)$. However, the high specificity of the pathogen to arrowhead plants might be a disadvantage for development as a mycoherbicide, because most chemical herbicides used in rice paddies control more than one species.

Chemical herbicides such as bensulfuron-methyl or pyrazosulfuron-ethyl have been used for controlling arrowhead as well as many other perennial paddy weeds, but these are known to be ineffective in controlling arrowhead because of its irregular emergence during the rice-growing season $(5,10)$. Under this situation, $P$. tabacinum could be suitable as a mycoherbicide because the fungus could kill continuously emerging arrowhead seedlings during a whole growing season. Alternatively, this fungus can be combined with other chemical herbicides or biological control agents such as Epicoccosorus nematosporus, specific only to water nutsedge (Eleocharis kuroguwai), to control multiple species of important, hard-to-control perennial weeds in rice paddy fields $(2,6,8)$.

The fungal inoculum was prepared easily by submerged culture, with conidia produced abundantly in common media such as PDB or cornmeal broth at 25 to $30^{\circ} \mathrm{C}$. This fact is one of the important components in the cost-effective mass production of inoculum required for developing the pathogen as a commercial mycoherbicide (2). Inoculation of a conidial suspension to arrowhead plants consistently reduced the plant stand during 2 years of field experiments.

For developing this pathogen as a mycoherbicide, various limitations in biological, technological, environmental, and economic aspects should be solved (14). For example, effective methods to lower the cost of mass production and formulation to improve the efficacy of the pathogen are needed. Additional field trials will be conducted to demonstrate consistent field effectiveness.

\section{ACKNOWLEDGMENTS}

We thank W. Gams, Centraalbureau voor Schimmelcultures, The Netherlands, for the identification of $P$. tabacinum; and R. Charudattan, Plant Pathology Department, University of Florida, for suggestions and corrections in the preparation of this manuscript.

\section{LITERATURE CITED}

1. Bost, S. C., and Mullins, C. A. 1992. A blight of cucurbits caused by Microdochium tabacinum. Plant Dis. 76:861.

2. Boyette, C. D., Quimby, P. C., Connick, W. J., Daigle, D. J., and Fulgham, F. E. 1991. Progress in the production, formulation, and application of mycoherbicides. Pages 209-222 in: Microbial Control of Weeds. D. O. Te Beest, ed. Chapman and Hall, Inc., New York.
3. Boyette, C. D., Quimby, P. C., Bryson, C. T. Egley, G. H., and Fulgham, F. E. 1993. Biological control of hemp sesbania (Sesbania exaltata) under field condition with Colletotrichum truncatum formulated in an invert emulsion. Weed Sci. 41:497-500.

4. Charudattan, R. 1996. Recent developments in the field of microbial herbicides. Pages 6384 in: Biopesticides for crop protection, The Research Center for New Bio-Materials in Agriculture, Suwon, Korea.

5. Cho, K. Y. 1989. The Establishment of a Screening System for Developing New Pesticides. Korea Ministry Sci. Technol. Rep. 603.

6. Christy, A. L., Herbst, K. A., Kostka, S. J., Mullen, J. P., and Carlson, P. S. 1993. Synergizing weed biocontrol agents with chemical herbicides. Pages 87-100 in: Pest Control with Enhanced Environmental Safety. S. O. Duke, J. J. Menn, and J. R. Plimmer, eds. American Chemical Society, Washington, DC

7. Chung, Y. R., Koo, S. J., Kim, H. T., and Cho, K. Y. 1993. Studies on the development of a mycoherbicide for controlling a perennial weed, arrowhead (Sagittaria trifolia L.) in rice paddies. (Abstr.). Kor. J. Plant Pathol. 9:322.

8. Hong, Y. K., Cho, J. M., Kim, J. C., and Uhm, J. Y. 1996. Identification, pathogenicity and host range of a potential bioherbicide, Epicoccosorus nematosporus, causing fingerprint stem blight on water chestnut, Eleocharis kuroguwai. Kor. J. Plant Pathol. 12:58-65.

9. Itoh, K., and Miyahara, M. 1988. Damage caused by an arrowhead (Sagittaria trifolia L.), a perennial paddy weed to rice cultivated under ordinary conditions. Weed Res. (Jpn.) 33:44-54.

10. Kwon, Y. W. 1993. Domination of perennial weeds and barnyard grass in rice paddy fields. Agrochem. Inf. 14(5):17-23.

11. Palm, M. E., Gams, W., and Nirenberg, H. I. 1995. Plectosporium, a new genus for Fusarium tabacinum, the anamorph of Plectosphaerella cucumerina. Mycologia 87:397406.

12. Pascoe, I. G., Nancarrow, R. J., and Copes, C. J. 1984. Fusarium tabacinum on tomato and other hosts in Australia. Trans. Brit. Mycol. Soc. 83:343-345.

13. Te Beest, D. O., Yang, X. B., and Cisar, C. R. 1992. The status of biological control of weeds with fungal pathogens. Annu. Rev. Phytopathol. 30:637-657.

14. Watson, A. K., and Wymore, L. A. 1990 Identifying limiting factors in the biocontrol of weeds. Pages 305-316 in: New Directions in Biological Control: Alternatives for Suppressing Agricultural Pests and Diseases. Alan R. Liss, Inc., New York.

15. Weidemann, G. J., and Te Beest, D. O. 1990. Biology of host range testing for biocontrol of weeds. Weed Technol. 4:465-470.

16. Zazzerini, A., and Tosi, L. 1987. New sunflower disease caused by Fusarium tabacinum. Plant Dis. 71:1043-1044. 